\title{
AVAILABLE STATUS AND CHANGING TREND OF MICRONUTRIENTS IN FLOODPLAIN SOILS OF BANGLADESH
}

\author{
M.M.H. Sarker ${ }^{1 *}$, A.Z.M. Moslehuddin ${ }^{2}$, M. Jahiruddin ${ }^{2}$ and M.R. Islam ${ }^{2}$ \\ ${ }^{1}$ Department of Soil Science, Sylhet Agricultural University, Sylhet-3100, Bangladesh \\ ${ }^{2}$ Department of Soil Science, Bangladesh Agricultural University, Mymensingh-2202, Bangladesh
}

\begin{abstract}
Soil micronutrient deficiency has arisen in Bangladesh as a consequence of soil fertility depletion with time. Increasing cropping intensity and cultivation of modern varieties with high yield potential are the major reasons of nutrient depletion from soil, which results in decline of crop yield. With an objective of studying delineation of soil micronutrient status, their depleting trend over time, relationship with other soil variables and interrelationship among micronutrients, a study was carried out in Old Meghna Estuarine Floodplain (AEZ 19) soils of the country. In the present study, soil analysis of top soils $(0-15 \mathrm{~cm}$ soil depth) shows that availability of $\mathrm{Zn}$ and $\mathrm{B}$ declined after a decade of time. However for other micronutrients, viz. $\mathrm{Cu}, \mathrm{Mn}$ and $\mathrm{Fe}$, still prevailing high status. Micronutrient levels of subsoil $(15-30 \mathrm{~cm}$ soil depth) were in general lower than those of top soils. The soil $\mathrm{Zn}$ had significant positive correlation with clay content $\left(r=0.712^{* *}\right)$ and its availability was found influenced more by clay fraction in case of higher $\mathrm{Zn}$ concentration $\left(>1.35 \mathrm{\mu g} \mathrm{g}^{-1}\right)$ than lower concentration $\left(<1.35 \mathrm{\mu g} \mathrm{g}^{-1}\right)$. The Cu content in soil was positively influenced by soil clay content $\left(r=0.267^{*}\right)$, organic matter content $\left(r=0.279^{\star}\right), \mathrm{N}$ content $\left(r=0.579^{\star *}\right)$ and $\mathrm{Mg}$ content $\left(r=0.364^{* *}\right)$, and was negatively influenced by soil $\mathrm{pH}\left(r=-0.347^{* *}\right)$ and $\mathrm{P}$ content $\left(r=-0.340^{*}\right)$. Concerning interrelationship among soil micronutrients, $\mathrm{Cu}$ content showed positive interaction with $\mathrm{Zn}$ content $(r=0.244)$ and negative interaction with B content $(r=-0.255)$. In sub soil, except soil $\mathrm{B}$ content, all other micronutrient contents were negatively correlated with soil $\mathrm{pH}$. Only $\mathrm{Cu}$ content was significantly correlated $\left(r=0.362^{* *}\right)$ with clay content. There exists positive relationship between soil organic matter and $\mathrm{Zn}\left(r=0.269^{\star}\right), \mathrm{Cu}\left(\mathrm{r}=0.357^{* *}\right)$ and Fe content $\left(r=0.362^{* *}\right)$. The $\mathrm{Zn}, \mathrm{Cu}$ and Fe content in soil was positively correlated with soil $\mathrm{N}$ content, $\mathrm{r}$ values being $0.455^{* *}, 0.526^{* *}$ and $0.659^{* *}$, respectively.
\end{abstract}

\footnotetext{
*Corresponding author email: mosharaf_srdi@yahoo.com
} 
Keywords: Micronutrients, status, nutrient depletion, trend, floodplain soil, Bangladesh.

\section{INTRODUCTION}

Bangladesh has an agro-based economy blessed with its fertile soil resources. In the recent years, huge pressure has been exerted on soil resources of the country to ensure food security for its ever increasing population. Intensification of agricultural land use has been increased remarkably, along with increasing use of modern crop varieties, which in turn has resulted in deterioration of soil fertility with emergence of new nutrient deficiencies. In 1983-84, the cropping intensity of the country was $171 \%$ whereas it was $183 \%$ in $2009-10$ (BBS, 2012). Accordingly, coverage of HYVs and hybrid varieties of only rice increased from 6499 thousand acres in 198384 to 23,461 thousand acres in 2011-12 (BBS, 2012). Thus, with advancement of time, soil fertility has declined (Islam, 2008; SRDI, 2010a; SRDI, 2010b); chronologically N, P, K, S, Zn and B deficiency have arisen in the country's soils (Jahiruddin and Sattar, 2010). Declining productivity in Bangladesh due to the decrease of soil fertility has been cited by many authors (Islam, 1990; Ali, 1991).

Thirty agro-ecological zones (AEZs) have been identified in Bangladesh on the basis of certain information of physical environment which are relevant for land use and assessing agricultural potential. Among the AEZs, Old Meghna Estuarine Floodplain (AEZ 19) is one of the intensively cropped agricultural zones covering considerably larger land area. The total land area under AEZ 19 is 774026 ha having major coverage of 14 districts of the country (FRG, 2012).

Among the micronutrients, zinc deficiency is widely reported. In early 1980 s, the $\mathrm{Zn}$ deficiencies in rice were observed. In early 1990's, the B deficiency of some crops is reported. There is sporadic information of $\mathrm{Cu}$, Mo and $\mathrm{Mn}$ deficiencies in crops (Bhuiyan et al., 1998). Deficiencies of $\mathrm{Fe}$ and $\mathrm{Cl}$ are not yet reported in Bangladesh. Considering the above facts, this study was conducted in the intensively cropped area covering AEZ 19 to search out the present status of micronutrients, their depleting trend over time, relationship of micronutrients with other soil variables and interrelationship among micronutrients.

\section{MATERIALS AND METHODS}

The bench mark information of fertility status in soils of the study area has generated and published by the Soil Resource Development Institute in respective Upazila Nirdeshikas (Adorsho Sadar and Burichong of Comilla district). For delineating the present fertility status, soil sampling was done from the representative sites of the study area in 2011-2012. The sampling sites were selected based on the land type and soil series. The corresponding previous sampling spots cited in respective Upazila Nirdeshika were also in consideration. Highest efforts were given for selecting closer spots to the previous sampling spots maintaining the other above mentioned criteria. GPS (Geological Positioning System) reading was recorded for each site. Fifty five 
sampling sites were selected, and from each site two samples were collected at two soil depths $(0-15 \mathrm{~cm}$ and $15-30 \mathrm{~cm})$. Maps showing the locations of selected soil sampling sites have included in figures $1 \& 2$.

The collected soil samples were spread on a brown paper in the laboratory for airdrying. After removing the plant roots and other debris, the air-dried soil was ground and passed through a 2-mm sieve for lab analysis. The processed samples were kept in polyethylene bags. Subsequently, the soil samples have been analyzed for basic soil properties ( $\mathrm{pH}$, organic matter and texture), macronutrients and micronutrients $(\mathrm{Cu}, \mathrm{Fe}, \mathrm{Mn}, \mathrm{Zn}$ and $\mathrm{B})$ status.

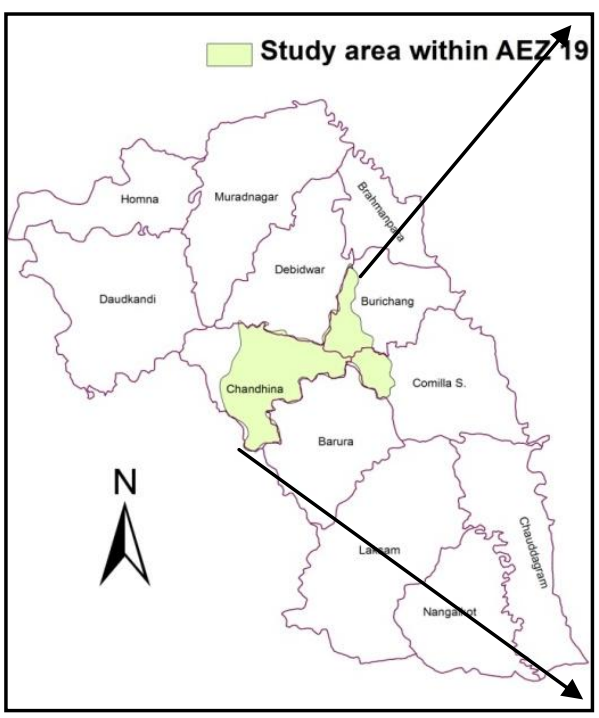

Figure 1. Location of study area in Comilla, Bangladesh

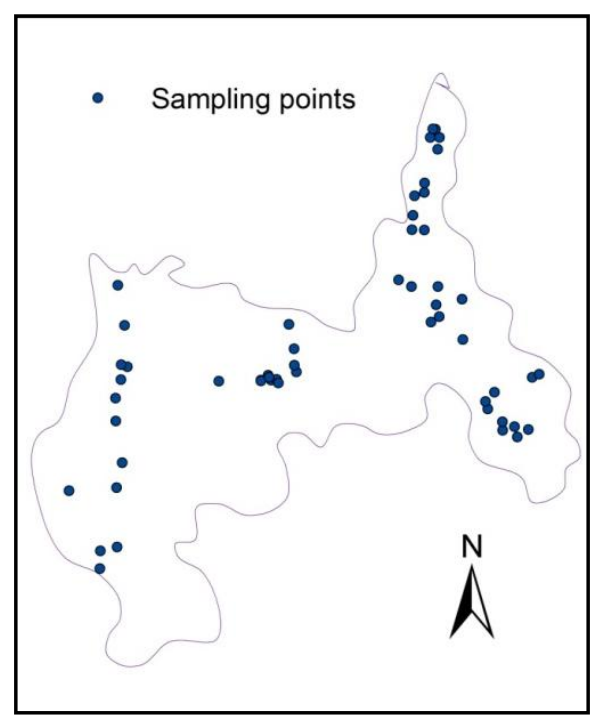

Figure 2. Study area showing sampling points

Soil $\mathrm{pH}$ was measured by glass electrode $\mathrm{pH}$ meter (McLean, 1982), texture by hydrometer method (Gee and Bauder, 1986), organic carbon by wet oxidation method (Nelson and Sommers, 1996), total $\mathrm{N}$ by micro-Kjeldahl method (Bremner and Mulvaney, 1982), available $\mathrm{P}$ for neutral and alkaline soil by Olsen method (Olsen and Sommers, 1982), available $\mathrm{P}$ for acidic soil by Bray and Kurtz method (Bray and Kurtz, 1945), exchangeable $\mathrm{K}, \mathrm{Ca} \& \mathrm{Mg}$ by $1 \mathrm{~N} \mathrm{CH}_{3} \mathrm{COONH}_{4}$ extraction (Knudsen et al., 1982), available $\mathrm{S}$ by $0.15 \% \mathrm{CaCl} 2$ extraction (Tabatabai, 1996), available $\mathrm{Zn}, \mathrm{Fe}, \mathrm{Mn} \& \mathrm{Cu}$ by DTPA extraction (Lindsay and Norvell, 1978) and available $\mathrm{B}$ by hot water- $0.02 \mathrm{M} \mathrm{CaCl}_{2}$ solution (1:2) extraction followed by determination using azomethine- $\mathrm{H}$ method (Keren, 1982).

Based on the analytical results of each micronutrient, soil samples were categorized into very low, low, medium, high and very high status (FRG, 2012). Relationship of each micronutrient with basic soil characteristics (clay content, $\mathrm{pH}$ and organic 
matter content) and macronutrients, and also interrelationship among different micronutrients were examined by correlation statistics (Gomez and Gomez, 1984). A comparison was also made between present soil test value and previous soil test values obtained from Upazila Nirdeshika. The analytical results derived from collected soil samples and Upazila Nirdeshika is denoted in this manuscript as present and previous status, respectively. The soil samples for preparing the respective Upazila Nirdeshikas were collected by SRDI in 1997-2002. Standard statistical tools were used in comparing the data.

\section{RESULTS}

\section{Present status of soil micronutrients and comparison with respective previous status}

A summary statistics of soil data with the information of maximum, minimum, mean and standard deviation for each micronutrient is presented in Table 1. For easy comparison, previous status of the micronutrients in top soil only is also provided in the same table. Present status of each micronutrient was compared with their previous status, as depicted in Upazila Nirdeshika, 1996-2003 (SRDI, 1999; SRDI, 2000; SRDI, 2006). Thus there was almost a decade of time gap between present and previous results. The comparative features between present and previous status of different micronutrients are shown in figures 3-7.

Table 1. Summary statistics of zinc, boron, copper, iron and manganese levels (mg $\left.\mathrm{kg}^{-1}\right)$ of soils at two depths $(\mathrm{n}=55)$

a) Present status

\begin{tabular}{c|c|c|c|c|c|c|c|c}
\hline \multirow{2}{*}{ Micronutrients } & \multicolumn{4}{|c|}{$0-15 \mathrm{~cm}$ depth } & \multicolumn{4}{c}{$15-30 \mathrm{~cm}$ depth } \\
\cline { 2 - 9 } & Min. & Max. & Mean & s.d & Min. & Max. & Mean & s.d \\
\hline Zn & 0.62 & 4.41 & 1.48 & 0.754 & 0.37 & 2.45 & 0.82 & 0.450 \\
$\mathrm{~B}$ & 0.10 & 0.57 & 0.291 & 0.090 & 0.07 & 0.32 & 0.19 & 0.061 \\
$\mathrm{Cu}$ & 1.12 & 7.62 & 2.56 & 1.066 & 0.55 & 9.46 & 2.19 & 1.600 \\
$\mathrm{Fe}$ & 44.0 & 428 & 215 & 81.40 & 11.0 & 375 & 79.0 & 66.70 \\
$\mathrm{Mn}$ & 3.00 & 141 & 24.8 & 26.91 & 3.95 & 100 & 20.0 & 20.90 \\
\hline
\end{tabular}


b) Previous status

\begin{tabular}{c|c|c|c|c}
\hline \multirow{2}{*}{ Micronutrients } & \multicolumn{4}{|c}{ 0-15 cm soil depth } \\
\cline { 2 - 5 } & Min. & Max. & Mean & s.d \\
\hline $\mathrm{Zn}$ & 0.80 & 6.20 & 1.83 & 1.210 \\
$\mathrm{~B}$ & 0.04 & 1.33 & 0.37 & 0.235 \\
$\mathrm{Cu}$ & 0.85 & 4.70 & 2.25 & 0.797 \\
$\mathrm{Fe}$ & 35.0 & 470 & 201 & 68.90 \\
$\mathrm{Mn}$ & 4.00 & 148 & 41.2 & 33.5 \\
\hline
\end{tabular}

Min.- Minimum, Max.-Maximum, s.d- Standard deviation

\section{Zinc status}

The available $\mathrm{Zn}$ (DTPA extractable) content of soil samples at $0-15 \mathrm{~cm}$ depth varied from $0.62-4.41 \mathrm{mg} \mathrm{kg}^{-1}$ with a mean value of $1.48 \mathrm{mg} \mathrm{kg}^{-1}$ (Table 1). The previous result of top soil $\mathrm{Zn}$ in this AEZ ranged from 0.80 to $6.20 \mathrm{mg} \mathrm{kg}^{-1}$ having mean value of $1.83 \mathrm{mg} \mathrm{kg}^{-1}$. Based on the critical limit of $\mathrm{Zn}$ as $0.60 \mathrm{mg} \mathrm{kg}^{-1}$, the soil samples were classified into $20 \%$ low, $38 \%$ medium, $22 \%$ optimum, $5 \%$ high and $15 \%$ very high categories (FRG, 2012) (Figure 3). The corresponding previous status was 15, $29,31,4$ and $22 \%$, respectively. Concerning subsoil $\mathrm{Zn}$ status, it ranged from 0.37$2.45 \mathrm{mg} \mathrm{kg}^{-1}$ having mean result of $0.82 \mathrm{mg} \mathrm{kg}^{-1}$.

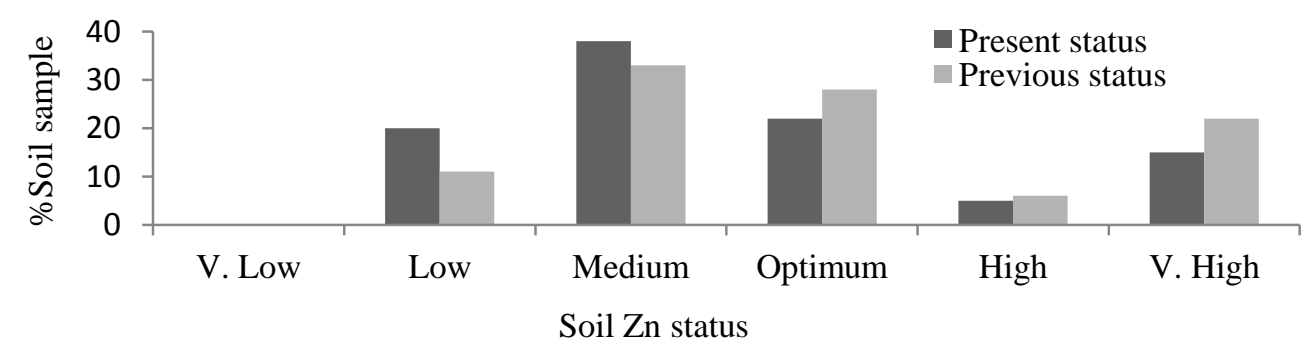

Figure 3. Changing trend of soil available $\mathrm{Zn}$ status over time in AEZ 19

\section{Boron status}

The available B status of top soil ranged from 0.10 to $0.57 \mathrm{mg} \mathrm{kg}^{-1}$ and 0.04 to 1.33 $\mathrm{mg} \mathrm{kg}{ }^{-1}$ having mean values of 0.29 and $0.37 \mathrm{mg} \mathrm{kg}^{-1}$ in the present and previous time, respectively (Table 1). The present B status of top soil can be grouped into $2 \%$ very low, 58\% low, 35\% medium and 5\% optimum against previous status of 5\% very low, $40 \%$ low, $29 \%$ medium, $11 \%$ optimum, $2 \%$ high and $13 \%$ very high, respectively (FRG, 2012) (Figure 4). The present subsoil B status was found to vary from $0.07-0.32 \mathrm{mg} \mathrm{kg}^{-1}$ where the average value being $0.19 \mathrm{mg} \mathrm{kg}^{-1}$. 


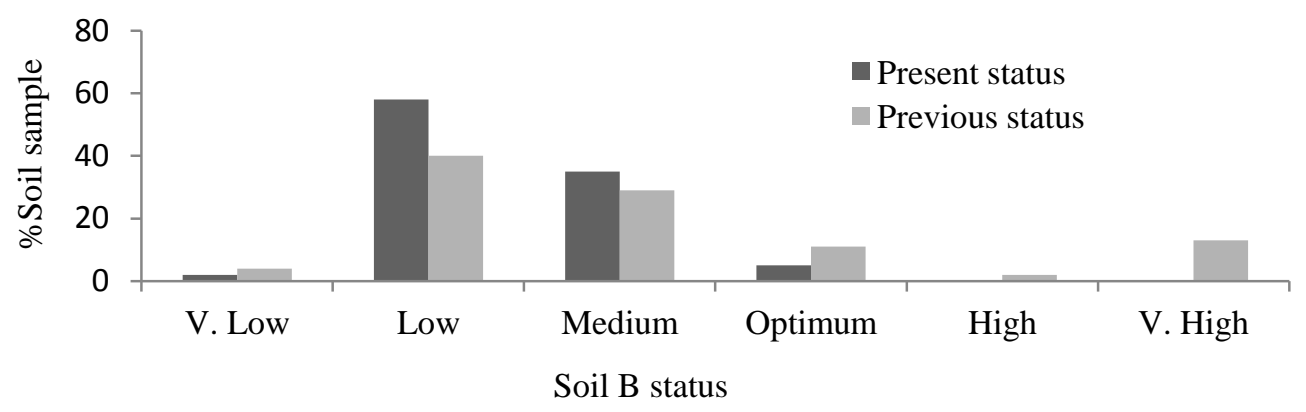

Figure 4. Changing trend of soil available B status over time in AEZ 19

\section{Copper status}

The available $\mathrm{Cu}$ content of top soil varied from $1.12-7.62 \mathrm{mg} \mathrm{kg}^{-1}$ with a mean value of $2.56 \mathrm{mg} \mathrm{kg}^{-1}$ (Table 1). Previously this $\mathrm{Cu}$ value was $0.85 \mathrm{mg} \mathrm{kg}^{-1}$ as the minimum, $4.70 \mathrm{mg} \mathrm{kg}^{-1}$ as the maximum and $2.25 \mathrm{mg} \mathrm{kg}^{-1}$ as the mean. The soil $\mathrm{Cu}$ status was of $100 \%$ very high for both present and previous cases (Figure 5). Concerning subsoil $\mathrm{Cu}$ status, it ranged from $0.55-9.46 \mathrm{mg} \mathrm{kg}^{-1}$ having mean value of $2.19 \mathrm{mg} \mathrm{kg}^{-1}$.

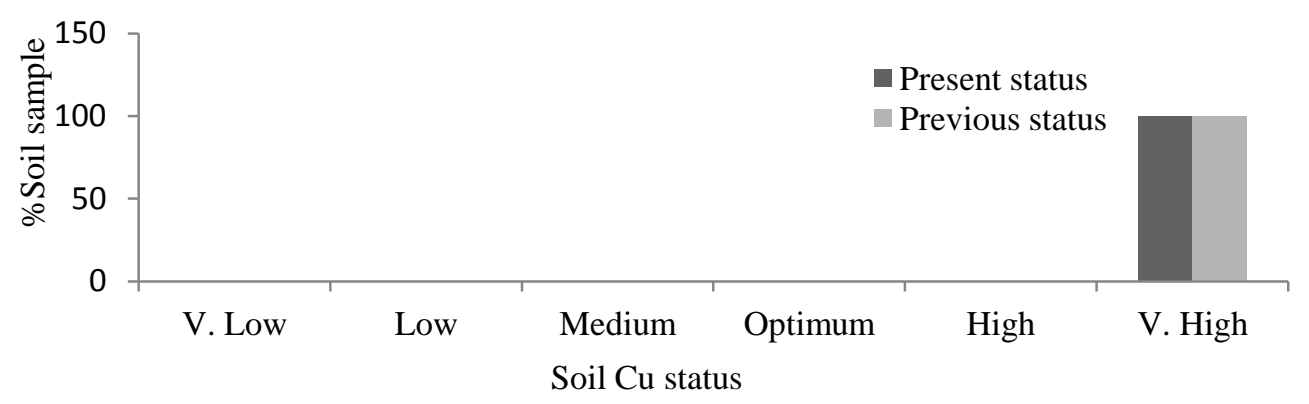

Figure 5. Changing trend of soil available $\mathrm{Cu}$ status over time in AEZ 19

\section{Iron status}

The soil status of available Fe was $100 \%$ very high in both present and previous situations (Figure 6) and it ranged from 44 to 428 and 35 to $470 \mathrm{mg} \mathrm{kg}^{-1}$ with the mean values of 215 and $201 \mathrm{mg} \mathrm{kg}^{-1}$, respectively (Table 1). Concerning subsoil Fe status, the lowest, highest and mean values were $11.0,375$ and $79.0 \mathrm{mg} \mathrm{kg}^{-1}$, respectively. 


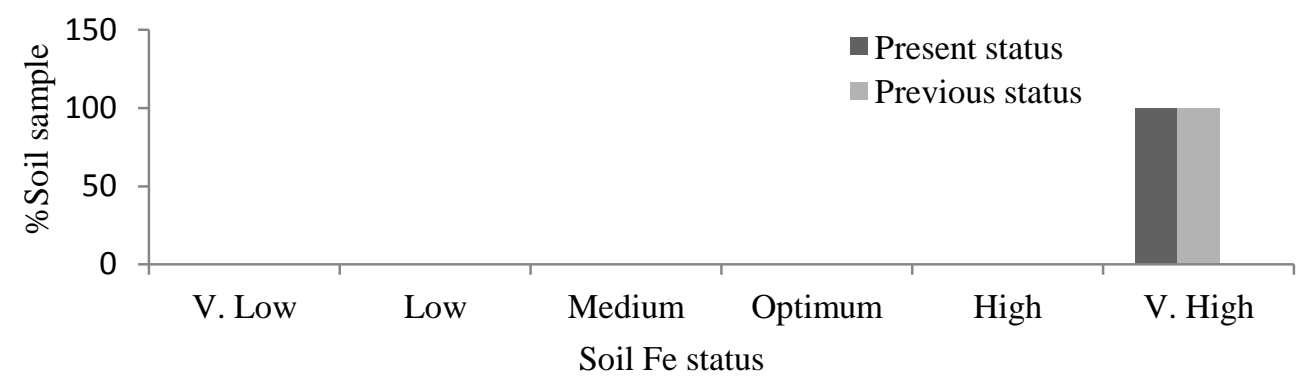

Figure 6. Changing trend of soil available Fe status over time in AEZ 19

\section{Manganese status}

The available Mn level of soil samples at $0-15 \mathrm{~cm}$ depth varied from 3.0-141.2 $\mathrm{mg}$ $\mathrm{kg}^{-1}$ with a mean level of $24.8 \mathrm{mg} \mathrm{kg}^{-1}$ (Table 1). According to FRG (2012) $2 \%$ soil had optimum Mn status, $2 \%$ high status and $96 \%$ very high status. Thus, no question of Mn deficiency arises in this AEZ's soils (Figure 7). On the other hand, previous status of soil Mn was between 4.0 and $148 \mathrm{mg} \mathrm{kg}^{-1}$ having a mean value of $41.2 \mathrm{mg}$ $\mathrm{kg}^{-1}$. These results assumed to be an indication of declining Mn status in the Old Meghna Estuarine Floodplain (AEZ 19) soils. The subsoil status of Mn was lower compared to top soil status. It ranged from $3.95-100 \mathrm{mg} \mathrm{kg}^{-1}$ and the average value being $20 \mathrm{mg} \mathrm{kg}^{-1}$.

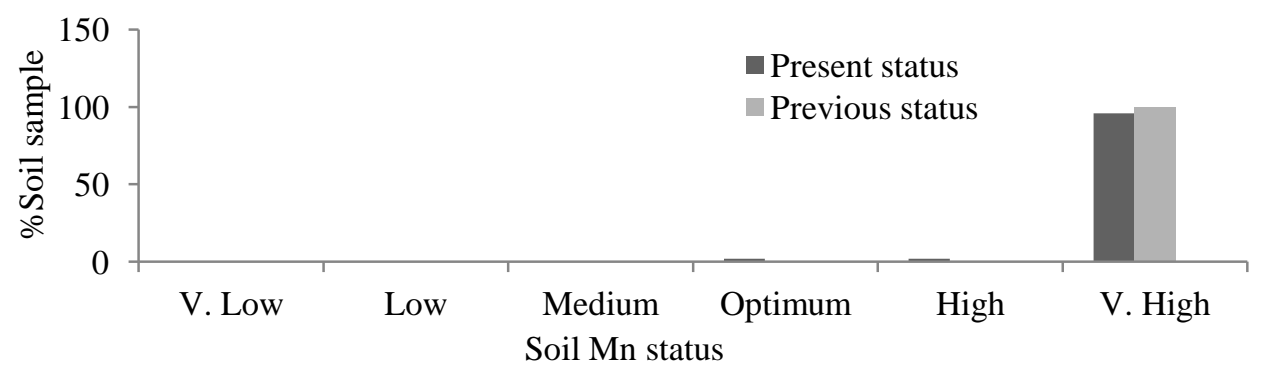

Figure 7. Changing trend of soil available Mn status over time in AEZ 19

Relationship of present micronutrients status with other soil properties and interrelation among the micronutrients

Correlation statistics was performed to examine the relationship of micronutrients with other soil variables and to see the interrelationship among the micronutrients. This statistics was done separately for top soils and sub-soils. These data are presented in tables $2 \& 3$. The number of soil samples i.e. observations for both cases were 55 . 


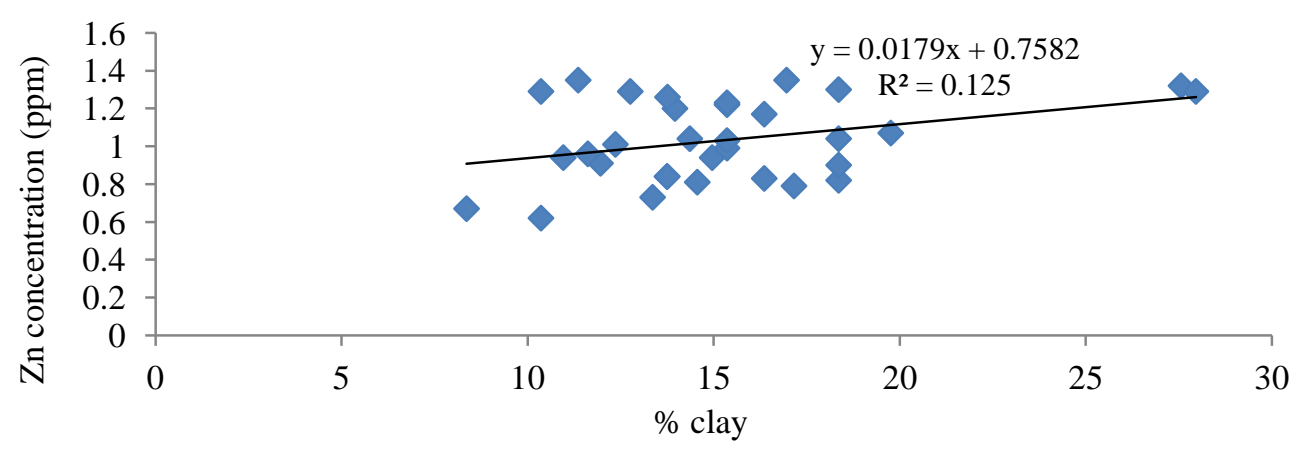

Figure 8. Relationship between $\mathrm{Zn}$ concentration $(<1.35 \mathrm{ppm})$ and clay content of soil

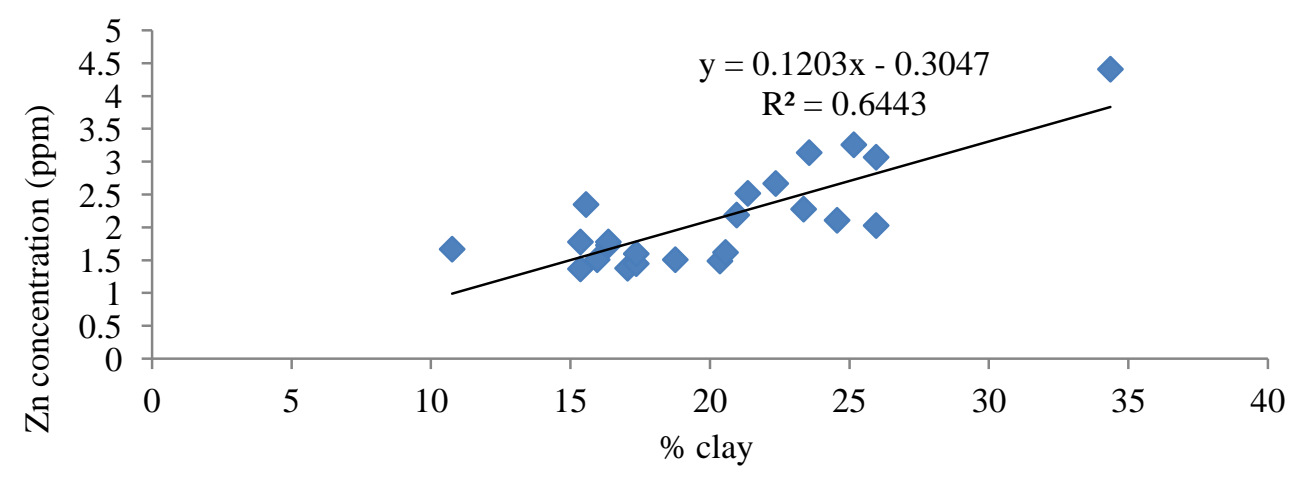

Figure 9. Relationship between $\mathrm{Zn}$ concentration (> $1.35 \mathrm{ppm})$ and clay content of soil

\section{Top soil characteristics}

The statistical analysis shows that soil $\mathrm{Zn}$ had significant and positive correlation with clay content $\left(\mathrm{r}=0.712^{* *}\right)$ meaning that soil available $\mathrm{Zn}$ content increases as the soil clay content increases (Table 2). The Zn availability was influenced more by clay fraction in case of higher $\mathrm{Zn}$ concentration $\left(>1.35 \mu \mathrm{g} \mathrm{g}^{-1}\right)$ than the lower concentration $\left(<1.35 \mu \mathrm{g} \mathrm{g}^{-1}\right)$ (Figures $\left.8-9\right)$. The $\mathrm{Zn}$ content showed no significant relationship with any other soil variables. Among the micronutrients under study, soil B content only exhibited significant positive relationship with soil $\mathrm{S}$ content $(r=$ 
$0.315^{* *}$ ), but it did not show significant correlation with other soil characteristics. Negative correlation with soil B was observed with clay content, organic matter, N, $\mathrm{K}$ and $\mathrm{Ca}$ content. Unlike other micronutrients, the $\mathrm{Cu}$ availability in soil was influenced by many soil variables. The $\mathrm{Cu}$ content in soil was positively influenced by soil clay content $(\mathrm{r}=0.267 *)$, organic matter content $\left(\mathrm{r}=0.279^{*}\right)$, $\mathrm{N}$ content $\left(\mathrm{r}=0.579^{* *}\right)$ and $\mathrm{Mg}$ content $\left(\mathrm{r}=0.364^{* *}\right)$, and was negatively influenced by soil $\mathrm{pH}$ $\left(\mathrm{r}=-0.347^{* *}\right)$ and $\mathrm{P}$ content $\left(\mathrm{r}=-0.340^{*}\right)$. The availability of $\mathrm{Fe}$ in soil was slightly affected by soil $\mathrm{pH}(\mathrm{r}=-0.251)$ and was highly influenced by soil organic matter $\left(\mathrm{r}=0.382^{* *}\right)$ and $\mathrm{N}$ content $\left(\mathrm{r}=0.356^{* *}\right)$. Unlike other micronutrients, the soil $\mathrm{Mn}$ level did not show significant relationship with any other soil properties. Concerning interrelationship among soil micronutrients, soil $\mathrm{Cu}$ content showed positive interaction with soil $\mathrm{Zn}$ content $(\mathrm{r}=0.244)$ and negative interaction with soil B content $(r=-0.255)$. Soil Fe or Mn content did not show significant interaction with other micronutrients ( $\mathrm{Zn}, \mathrm{Cu}$ and $\mathrm{B}$ ) in soil (Table 2).

\section{Subsoil characteristics}

Availability of micronutrients especially $\mathrm{Zn}, \mathrm{Cu}$ and $\mathrm{Fe}$ in sub soils was markedly affected or influenced by many other soil variables (Table 3). Soil B availability was not at all affected or influenced by any other soil characteristics under study. Except soil B content, all other micronutrient contents were negatively correlated with soil $\mathrm{pH}$ indicating that micronutrient availability decreases as soil $\mathrm{pH}$ increases and viceversa. This point is very important for soil fertility concern. Only $\mathrm{Cu}$ content was significantly correlated $(\mathrm{r}=0.362 * *)$ with clay content. There exists positive relationship between soil organic matter and soil $\mathrm{Zn}\left(\mathrm{r}=0.269^{*}\right), \mathrm{Cu}\left(\mathrm{r}=0.357^{* *}\right)$ and $\mathrm{Fe}\left(\mathrm{r}=0.362^{* *}\right)$ content. The $\mathrm{Zn}, \mathrm{Cu}$ and $\mathrm{Fe}$ content in soil was positively correlated with soil $\mathrm{N}$ content, $\mathrm{r}$ values being $0.455^{* *}, 0.526^{* *}$ and $0.659^{* *}$, respectively. Soil $\mathrm{P}$ content was only associated with $\mathrm{Zn}\left(\mathrm{r}=0.318^{*}\right)$ and $\mathrm{Fe}\left(\mathrm{r}=0.382^{* *}\right)$ content. The level of basic cations viz. $\mathrm{K}, \mathrm{Ca} \& \mathrm{Mg}$ was found positively associated with soil $\mathrm{Zn}$ and $\mathrm{Cu}$ content in soil. Micronutrient availability in soil did not depend on soil $\mathrm{S}$ content. Looking at the interactions of micronutrient availability in sub-soil, there was a positive interaction of $\mathrm{Zn}-\mathrm{Cu}, \mathrm{Zn}-\mathrm{Fe}, \mathrm{Zn}-\mathrm{Mn}$ and $\mathrm{Fe}-\mathrm{Cu}$. The other interactions were not significant (Table 3 ).

Table 2. Correlation matrix of soil variables (soil collection at $0-15 \mathrm{~cm}$ depth)

a) Relationship of micronutrients with other soil variables $(\mathrm{n}=55)$

\begin{tabular}{c|c|c|c|c|c|c|c|c|c}
\hline Micronutrients & Clay & $\mathrm{pH}$ & $\mathrm{OM}$ & $\mathrm{N}$ & $\mathrm{P}$ & $\mathrm{K}$ & $\mathrm{Ca}$ & $\mathrm{Mg}$ & $\mathrm{S}$ \\
\hline $\mathrm{Zn}$ & $0.712^{* *}$ & $-0.105 \mathrm{~ns}$ & $-0.002 \mathrm{~ns}$ & $0.032 \mathrm{~ns}$ & $0.227 \mathrm{~ns}$ & $0.212 \mathrm{~ns}$ & $0.206 \mathrm{~ns}$ & $0.014 \mathrm{~ns}$ & $0.188 \mathrm{~ns}$ \\
$\mathrm{~B}$ & $-0.090 \mathrm{~ns}$ & $0.100 \mathrm{~ns}$ & -0.111 & $-0.145 \mathrm{~ns}$ & $0.020 \mathrm{~ns}$ & $-0.029 \mathrm{~ns}$ & $-0.110 \mathrm{~ns}$ & $0.044 \mathrm{~ns}$ & $0.315^{*}$ \\
$\mathrm{Cu}$ & $0.267 *$ & $-0.347 * *$ & $0.279 *$ & $0.579 * *$ & $-0.340^{*}$ & $-0.006 \mathrm{~ns}$ & $0.209 \mathrm{~ns}$ & $0.364 * *$ & $-0.144 \mathrm{~ns}$ \\
$\mathrm{Fe}$ & $0.101 \mathrm{~ns}$ & $-0.251 \mathrm{~ns}$ & $0.382^{* *}$ & $0.356 * *$ & $-0.078 \mathrm{~ns}$ & $-0.229 \mathrm{~ns}$ & $0.071 \mathrm{~ns}$ & $0.024 \mathrm{~ns}$ & $0.061 \mathrm{~ns}$ \\
$\mathrm{Mn}$ & $0.176 \mathrm{~ns}$ & $0.001 \mathrm{~ns}$ & $-0.116 \mathrm{~ns}$ & $-0.024 \mathrm{~ns}$ & $-0.012 \mathrm{~ns}$ & $0.173 \mathrm{~ns}$ & $0.189 \mathrm{~ns}$ & $0.139 \mathrm{~ns}$ & $0.184 \mathrm{~ns}$ \\
\hline
\end{tabular}


(b) Interrelationship among micronutrients in soils $(\mathrm{n}=55)$

\begin{tabular}{c|c|c|c|c}
\hline Micronutrients & $\mathrm{Zn}$ & $\mathrm{B}$ & $\mathrm{Cu}$ & $\mathrm{Fe}$ \\
\hline $\mathrm{Zn}$ & - & & & \\
$\mathrm{B}$ & $-0.176 \mathrm{~ns}$ & - & & \\
$\mathrm{Cu}$ & $0.244 \mathrm{~ns}$ & $-0.255 \mathrm{~ns}$ & - & \\
$\mathrm{Fe}$ & $-0.063 \mathrm{~ns}$ & $0.112 \mathrm{~ns}$ & $0.211 \mathrm{~ns}$ & - \\
$\mathrm{Mn}$ & $0.202 \mathrm{~ns}$ & $-0.181 \mathrm{~ns}$ & $0.133 \mathrm{~ns}$ & $-0.136 \mathrm{~ns}$ \\
\hline
\end{tabular}

$*=$ Significant at $5 \%$ level, $* *=$ Significant at $1 \%$ level, $\mathrm{ns}=$ Not significant

Table 3. Correlation matrix of soil variables (soil collection at $15-30 \mathrm{~cm}$ depth)

a) Relationship of micronutrients with other soil variables $(n=55)$

\begin{tabular}{|c|c|c|c|c|c|c|c|c|c|}
\hline Micronutrients & Clay & $\mathrm{pH}$ & $\mathrm{OM}$ & $\mathrm{N}$ & $\mathrm{P}$ & $\mathrm{K}$ & $\mathrm{Ca}$ & $\mathrm{Mg}$ & $S$ \\
\hline $\mathrm{Zn}$ & $-0.070 \mathrm{~ns}$ & $-0.397 * *$ & $0.269 *$ & $0.455^{* *}$ & $0.318^{*}$ & $0.422 * *$ & $0.374 *$ & $0.313^{*}$ & $0.115 \mathrm{~ns}$ \\
\hline B & $-0.013 \mathrm{~ns}$ & 0.212 & $-0.025 \mathrm{~ns}$ & $-0.147 \mathrm{~ns}$ & $\stackrel{-}{0.100 \mathrm{~ns}}$ & $-0.193 n s$ & $0.017 \mathrm{~ns}$ & $0.011 \mathrm{~ns}$ & $0.119 \mathrm{~ns}$ \\
\hline $\mathrm{Cu}$ & $0.362 * *$ & $-0.323 *$ & $0.357 * *$ & $0.526^{* *}$ & $0.042 \mathrm{~ns}$ & $0.573 * *$ & $0.342 *$ & $0.484 * *$ & $-0.005 \mathrm{~ns}$ \\
\hline $\mathrm{Fe}$ & $-0.096 \mathrm{~ns}$ & $-0.626 * *$ & $0.362 * *$ & $0.659 * *$ & $0.282 *$ & $0.214 \mathrm{~ns}$ & $0.144 \mathrm{~ns}$ & $\begin{array}{c}- \\
0.065 \mathrm{~ns}\end{array}$ & $-0.007 \mathrm{~ns}$ \\
\hline Mn & $0.009 \mathrm{~ns}$ & $-0.365 * *$ & $0.147 \mathrm{~ns}$ & $0.182 \mathrm{~ns}$ & $0.219 \mathrm{~ns}$ & $0.195 \mathrm{~ns}$ & $0.080 \mathrm{~ns}$ & $0.107 \mathrm{~ns}$ & $0.098 \mathrm{~ns}$ \\
\hline
\end{tabular}

(b) Interrelationship among micronutrients in soils $(n=55)$

\begin{tabular}{c|c|c|c|c}
\hline Micronutrients & $\mathrm{Zn}$ & $\mathrm{B}$ & $\mathrm{Cu}$ & $\mathrm{Fe}$ \\
\hline $\mathrm{Zn}$ & - & & & \\
$\mathrm{B}$ & $-0.065 \mathrm{~ns}$ & - & & \\
$\mathrm{Cu}$ & $0.381^{* *}$ & $-0.171 \mathrm{~ns}$ & - & - \\
$\mathrm{Fe}$ & $0.402^{* *}$ & $0.157 \mathrm{~ns}$ & $0.272^{*}$ & - \\
$\mathrm{Mn}$ & $0.364^{* *}$ & $-0.041 \mathrm{~ns}$ & $0.188 \mathrm{~ns}$ & $0.110 \mathrm{~ns}$ \\
\hline
\end{tabular}

$*=$ Significant at $5 \%$ level, $* *=$ Significant at $1 \%$ level, $\mathrm{ns}=$ Not significant

\section{DISCUSSION}

\section{Comparison of micronutrients status from its present to past in soils under investigation}

In the current study, $80 \%$ soil samples $(0-15 \mathrm{~cm})$ has been grouped as low to optimum categories considering $\mathrm{Zn}$ status and $98 \%$ samples of same soil depth lied in low to medium categories on the basis of B content. According to FRG (2012), low to medium $\mathrm{Zn}$ status and low to optimum B status prevailed in soils of AEZ 19. Hence, slight negative changes were observed in soil zinc and boron status of the 
study area after almost a decade of time. High cropping intensity accompanied with cultivation of modern varieties of crop might be worsening the situation. This result has an agreement with SRDI (2010b) where Comilla was shown as one of the most B deficient areas in Bangladesh. There is a good agricultural practice in that area; the crop residues especially in case of rice, maximum parts of straw are left in the field while crop harvesting. But later on, some other needy people collect those for using as fuel. If those crop residues could be incorporated in soil, there would be a positive amendment of soil. Again, there is a gap of two months in between aus rice and next rabi crops in vegetable-vegetable/maize-aus rice cropping pattern in that area. This gap could be used for producing green manure. Besides, other appropriate fertilizer management programs should be associated to reduce nutrient depletion from soils of that area. In the study area, very high status of available $\mathrm{Cu}, \mathrm{Mn}$ and $\mathrm{Fe}$ prevailed as it was in the previous year of consideration. The soil $\mathrm{Cu}$ and $\mathrm{Fe}$ have not declined; moreover there was an indication of slight increased soil Fe over time. It might be due to decreasing trend of soil $\mathrm{pH}$ in the study area; as $\mathrm{pH}$ is one of the most influential factors of iron availability in soil. In lower soil $\mathrm{pH}$, there is a tendency of higher availability of iron in soil. Generally, micronutrient status in surface soils (0$15 \mathrm{~cm})$ was found higher compared to subsoil $(15-30 \mathrm{~cm})$ status. The reason behind such condition could be attributed due to addition of fertilizers and manure to top soil. In addition to that, the probable reason for decreasing micronutrient content with soil depth could be due to the accumulation of biomass in the surface layer of soils leading to higher organic matter and clay content in the top soil than sub-soils. Similar investigation was reported by Vijayakumar et al. (2011). Typical micronutrient soil-profile distribution was likely a result of greater decomposition of soil organic matter and crop residues that contribute to micronutrient accumulation to the surface layers. Secondly, root distributions and rooting depth play an important role in shaping micronutrient profiles because nutrients taken up by deep roots are transported into the above-ground parts and re-deposited on the soil surface through stem flow and through fall (Garcia et al., 2014).

\section{Relationship of micronutrients status with other soil properties and their interrelations}

Among the micronutrients $\mathrm{Zn}$ and $\mathrm{Cu}$ had significant positive relation with clay content in top soil, while in sub soil only $\mathrm{Cu}$ had significant positive relation. This might be due to the availability of binding sites for different cations on the clay particles. Sharma et al. (2004) found that the total content of $\mathrm{Zn}, \mathrm{Cu}, \mathrm{Fe}$ and $\mathrm{Mn}$ increased with an increase in soil clay content. Mustapha and Fagam (2007) also found significant positive relation between soil $\mathrm{Zn}$ and clay content. Soil available B was negatively correlated with clay content while $\mathrm{Fe}$ and $\mathrm{Mn}$ associated positively but the relations were non-significant. Worku et al. (2016) also found negative significant correlation between soil $\mathrm{B}$ and clay content $\left(\mathrm{r}=-0.46^{* *}\right)$. Soil $\mathrm{pH}$ was negatively correlated with $\mathrm{Zn}, \mathrm{Cu}$ and $\mathrm{Fe}$ in top soil, and $\mathrm{Zn}, \mathrm{Cu}, \mathrm{Fe}$ and $\mathrm{Mn}$ in sub surface soil. Worku et al. (2016) also found weak as well as negative association $(r=$ 
-0.16) between $\mathrm{Cu}$ and $\mathrm{pH}$ values. Njukeng et al. (2013) also reported non-significant negative correlation between soil $\mathrm{pH}$ and $\mathrm{Fe}$ content $(\mathrm{r}=-0.04)$. Available $\mathrm{Cu}$ and $\mathrm{Fe}$ had strong association with soil organic matter content. This result is in agreement with Worku et al. (2016).

In case of interrelationship among the micronutrients, available $\mathrm{Zn}$ showed positive relation with $\mathrm{Cu}$ and $\mathrm{Mn}$ in top soil. In addition to that Fe was strongly correlated with available $\mathrm{Zn}$. This finding has an agreement with Srivastava et al. (2017), who reported positive relation of $\mathrm{Zn}$ with $\mathrm{Mn}(\mathrm{r}=0.031)$ and $\mathrm{Cu}(\mathrm{r}=0.098)$. The available $\mathrm{B}$ content had negative relation with most of the micronutrients studied, since positive charge of micronutrients like $\mathrm{Fe}, \mathrm{Mn}$ and $\mathrm{Cu}$ influence antagonism for the availability of non metal B ion to the plants. These results were also supported by Srivastava et al. (2017) and Vijayakumar et al. (2011).

\section{CONCLUSION}

Like macronutrients soil micronutrient deficiency has also arisen in floodplain soils of Bangladesh with advancement of time. The relationships between soil micronutrients and other soil parameters as well as soil macronutrients which were explored through this study may help in soil management practices in the study areas.

\section{ACKNOWLEDGEMENT}

We gratefully acknowledge the financial support provided by Coordinated Project on Soil Fertility and Fertilizer Management for Crops and Cropping Patterns (BAU component), NATP, BARC during the research period.

\section{REFERENCES}

Ali, M.I. (1991).Sustainable land management in Bangladesh-A strategic overview. In: Proc. Int. on Evaluation for Sustainable Land Management in the Developing World, Chiang Rai, Thailand, No. 12, pp. 123-125.

BBS. (2012).Bangladesh Bureau of Statistics. The Year Book of Agricultural Statistics of Bangladesh. Statistics and Informatics Division, Ministry of Planning, Government of the People's Republic of Bangladesh, Dhaka. P. 199.

Bhuiyan, M.A.H, Khanam, D., Khatun, M.R., and Hassan, M.S.(1998).Effects of molybdenum, boron and Rhizobium on nodulation, growth and yield of chickpea, Bulletin Institute of Tropical Agriculture Kyushu University, 21, 1-7.

Bray, R.H., and Kurtz, L.T. (1945).Determination of total, organic and available forms of phosphorus in soils. Soil Science, 59, 39-45.

Bremner, J.M., and Mulvaney, C.S. (1982).Total nitrogen. In: Methods of soil analysis, part 2, chemical and microbiological properties, A.L. Page, R.H. Miller and D.R. Keeney (eds.), p. 595-624. American Society Agronomy Inc., Madison, Wisconsin, USA. 
FRG. (2012).Fertilizer Recommendation Guide. Bangladesh Agricultural Research Council (BARC), Dhaka, Bangladesh.

García-Marco, S., Gómez-Rey, M.X., and González-Prieto, S.J. (2014).Availability and uptake of trace elements in a forage rotation under conservation and plough tillage. Soil and Tillage Research, 137, 33-42.

Gee, G.W., and Bauder, J.W. (1986).Particle size Analysis. In: Methods of Soil Analysis, Part 1 ( $2^{\text {nd }}$ edition), A. Klute (ed.), p. 383-411, American Society of Agronomy Inc. and Soil Science Society of America Inc., Madison, Wisconsin, USA.

Gomez, K.A., and Gomez, A.A. (1984).Statistical Procedures for Agricultural Research, John Wiley and Sons, New York.

Islam, M.S. (2008).Soil fertility history, present status and future scenario in Bangladesh, Bangladesh Journal of Agriculture and Environment, 4, 129-151.

Islam, S. (1990).The decline of soil quality. In: Environmental aspect of agricultural development in Bangladesh, S. Huq, A.A. Rahman, and G.R. Conway (ed.), The University Press Limited, Dhaka.

Jahiruddin, M., and Sattar, M.A. (2010).Agricultural Research Priority: Vision 2030 and beyond. Bangladesh Agricultural Research Council.

Keren, R. (1996).Boron. In: Methods of soil analysis, part 3, Chemical methods, D.L. Sparks, A.L. Page, P.A. Helmke, R.H. Loeppert, P.N. Soltanpour, M.A. Tabatabai, C.T. Johnston and M.E. Sumner (eds.), p. 603-626. American Society of Agronomy Inc., Madison, Wisconsin, USA.

Knudsen, D., Peterson, G.A., and Pratt, P.F. (1982).Lithium, Sodium, and Potassium. In: Methods of Soil Analysis, Part 2, Chemical and Microbiological Properties, A.L. Page, R.H. Miller and D.R. Keeney (eds.), p. 225-246. American Society of Agronomy Inc., Madison, Wisconsin, USA.

Lindsay, W.L., and Norvell, W.A. (1978). Development of a DTPA soil test for Zn, Fe, Mn and Cu. Soil Science Society of America Journal, 42, 421-428.

McLean, E.O. (1982). Soil pH and Lime Requirement. In: Methods of Soil Analysis, Part 2, Chemical and Microbiological Properties, A.L. Page, R.H. Miller and D.R. Keeney (eds.), p. 199-224. American Society of Agronomy Inc., Madison, WI, USA.

Mustapha, S., and Fagam, A.S. (2007).Influence of parent marterial on the contents and distribution of B and $\mathrm{Zn}$ in upland soils of Bauchi State, Nigeria. International Journal of Environmental Science and Technology, 4(3), 359-362.

Nelson, D.W., and Sommers, L.E. (1996).Total Carbon, Organic Carbon, and Organic Matter. In: Methods of Soil Analysis, Part 3, Chemical Methods, D.L. Sparks, A.L. Page, P.A. Helmke, R.H. Loeppert, P.N. Soltanpour, M.A. Tabatabai, C.T. Johnston and M.E. Sumner (eds.), p. 961-1010. American Society of Agronomy Inc., Madison, Wisconsin, USA.

Njukeng, J.N., Ehabe, E.E., Nkeng, G.E., Kratz, S., Schick, J., and Schnug, E. (2013). Investigations on the nutritional status of Hevea brasiliensis plantations in the humid forest zone of Cameroon Part 1: Micronutrient status and distribution in soils. Journal of Cultivated Plants, 65 (10), 369-375. 
Olsen, S.R., and Sommers, L.E. (1982).Phosphorus. In: Methods of Soil Analysis, Part 2, Chemical and Microbiological Properties, A.L. Page, R.H. Miller and D.R. Keeney (eds.), p. 403-430. American Society of Agronomy Inc., Madison, WI, USA.

Sharma, B.D., Arora, H., Kumar, R., and Nayyar, V.K. (2004).Relationships between soil characteristics and total and DTPA-extractable micronutrients in Inceptisols of Punjab. Communications in Soil Science and Plant Analysis, 35(5 \& 6), 799-818.

SRDI. (1999).Soil Resource Development Institute. Land and Soil Resources Utilization Guide (in Bengali). Thana Nirdeshika series-279. Adorsho Sadar upazila of Cumilla district, Bangladesh.

SRDI. (2000).Soil Resource Development Institute. Land and Soil Resources Utilization Guide (in Bengali). Thana Nirdeshika series-333. Burichong upazila of Cumilla district, Bangladesh.

SRDI. (2006).Soil Resource Development Institute. Land and Soil Resources Utilization Guide (in Bengali). Updated Upazila Nirdeshika series-24. Chandina upazila of Cumilla district, Bangladesh.

SRDI. (2010a).Soil Resource Development Institute. GIS map, Zinc Status of Bangladesh Soils. SRDI, Farmgate, Dhaka, Bangladesh.

SRDI. (2010b).Soil Resource Development Institute. GIS map, Boron Status of Bangladesh Soils. SRDI, Farmgate, Dhaka, Bangladesh.

Srivastava, P.P., Pandiaraj, T., Das, S., Sinha, S.K., and Sinha, A.K. (2017). “Assessment of micronutrient status in relation to soil characteristics under Tasar growing states of Bihar and Jharkhand", International Journal of Current Research, 9(4), 48710-48713.

Tabatabai, M.A. (1996).Sulphur. In: Methods of Soil Analysis, Part 3, Chemical Methods, D.L. Sparks, A.L. Page, P.A. Helmke, R.H. Loeppert, P.N. Soltanpour, M.A. Tabatabai, C.T. Johnston and M.E. Sumner (eds.), p. 921-960. American Society of Agronomy Inc., Madison, Wisconsin, USA.

Vijayakumar, R., Arokiaraj, A., and Martin, P.P. (2011). Micronutrients and their relationship with soil properties of natural disaster prone coastal soils. Journal of Chemical Sciences, 1(1), 8-12.

Worku, A., Bedadi, B., and Mohammed, M. (2016).Assessment on the status of some micronutrients of salt affected soils in Amibara area, Central rift valley of Ethiopia. Academia Journal of Agricultural Research, 4(8), 534-542. 